Revta brasil. Bot., São Paulo, V.23, n.2, p.217-224, jun. 2000

\title{
Pollination and other biotic interactions in figs of Ficus eximia Schott (Moraceae) ${ }^{1}$
}

\author{
RODRIGO AUGUSTO SANTINELO PEREIRA ${ }^{2,4}$, JOÃO SEMIR ${ }^{2}$ \\ and AYRES DE OLIVEIRA MENEZES JR. ${ }^{3}$
}

(received: November 5, 1998; accepted: March 9, 2000)

\begin{abstract}
Pollination and other biotic interactions in figs of Ficus eximia Schott (Moraceae)). During the period from 1992 to 1997, interactions of several organisms and Ficus eximia figs, a monoecious species, were studied in plants located in Campinas/SP and Londrina/PR (Brazil). Ficus eximia is pollinated by a single fig wasp species, Pegoscapus sp. (Hymenoptera: Agaonidae, Agaoninae), but also visited by other 14 non-pollinating wasps (Agaonidae, Eurytomidae, Torymidae). Mites (Tarsonemidae), nematodes (Diplogasteridae) and fungi which use the body of the pollinating fig wasp to disperse themselves were also observed.

RESUMO - (Polinização e outras interações bióticas em sicônios de Ficus eximia Schott (Moraceae)). Durante o período de 1992 a 1997, as interações de vários organismos e figos de Ficus eximia, uma espécie monóica, foram estudadas em plantas localizadas em Campinas/SP e Londrina/PR (Brasil). Ficus eximia é polinizada por uma única espécie de vespa de figo, Pegoscapus sp. (Hymenoptera: Agaonidae, Agaoninae), e associada a outras 14 espécies de vespas não-polinizadoras (Agaonidae, Eurytomidae, Torymidae). Ácaros (Tarsonemidae), nematóides (Diplogasteridae) e fungos, os quais utilizam o corpo da vespa polinizadora para se dispersarem, foram também observados.
\end{abstract}

Key words - Plant-animal interaction, mutualism, reproduction

\section{Introduction}

The genus Ficus is of great value for studies on ecological and evolutionary questions, due to its diversified system of biotic interactions with several groups of organisms (Compton et al. 1996). Species of Ficus are pollinated exclusively by females of species-specific small wasps (Hymenoptera: Agaonidae: Agaoninae) which depend on fig trees to deposit their eggs in ovaries of female flowers and to develop their offspring (Janzen 1979a, Wiebes 1979, Corner 1985, Murray 1985). Non-pollinating fig wasps (mainly belonging to subfamilies of Agaonidae other than Agaoninae, but also other families, sensu Boucek 1988) which gall female flowers or parasite galler larvae, and that show some host specificity, are also associated with Ficus inflorescences (Gordh 1975, Ramírez 1988, Boucek 1993, Bronstein 1991, 1992).

1. Financial support provided by CAPES.

2. Departamento de Botânica, Instituto de Biologia, Universidade Estadual de Campinas, Caixa Postal 6109, 13083-970 Campinas, SP, Brazil.

3. Departamento de Agronomia, Centro de Ciências Agrárias, Universidade Estadual de Londrina, Caixa Postal 6001, 86051-970 Londrina, PR, Brazil.

4. Corresponding author: rodrigo@obelix.unicamp.br
The Ficus inflorescence or syconium (hereafter referred as fig) is an urn-shaped receptacle with flowers on the inner surface and apically closed off by numerous bracts forming the ostiole (Crane 1986, Verkerke 1989). Thus, for pollination to take place, female pollinating wasps bearing pollen need to penetrate the ostiole, working as pollen vector. The fig is usually considered a "trap" to pollinating wasps (foundress), because after pollination and oviposition the foundress do not leave the fig and die inside it. However, Gibernau et al. (1996) reported, in three Ficus species, that some foundresses could leave the fig after pollination (re-emerge).

Galil (1977) divided the life cycles of the fig wasps and the fig into five well defined phases: pre-female phase, before female flowers are mature; female phase, when female flowers are receptive and pollinators enter the figs; interfloral phase, when wasp larvae and seeds are maturing; male phase, when anthers are mature and the wasp offspring emerge from their galls and female pollinating wasps collect the pollen before dispersing; post-floral phase, after fig wasps dispersion and when figs ripen, becoming attractive to dispersers.

Figs also support a fauna of insects other than wasps and a diverse group of organisms (Nadel et al. 1992, Compton 1993). This study describes the pollination and other biotic interactions that occur in 
figs of F. eximia growing naturally in two Brazilian localities.

\section{Material and methods}

Ficus eximia Schott (subgenus Urostigma, section Americana) belongs to the taxonomic $F$. citrifolia P. Miller-complex (C.C. Berg, personal communication). This taxon has received several names in different localities, such as $F$. guaranitica Chodat \& Vischer in Brazil (Carauta 1989) and F. hemsleyana Standley in Costa Rica (W. Ramírez B., personal communication). DeWolf (1960) lists 29 synonyms of $F$. citrifolia, among them $F$. eximia.

Ficus eximia is a monoecious tree that normally grows as epiphytic on other trees or edifications, frequently developing on anthropized areas. Figs are borne in pairs in the leaf axils and when mature reach $2-2.5 \mathrm{~cm}$ in diameter (figure 1). Fig production on each tree (normally referred as "crop") is generally highly synchronized, but fructification is asynchronic among different individuals (Pereira et al. 1995)

Plants of $F$. eximia growing in surroundings and on the UNICAMP campus (Campinas State University; Campinas/SP; $22^{\circ} 54^{\prime} \mathrm{S}, 4^{\circ} 03^{\prime} \mathrm{W}$ ) and on the UEL campus (Londrina State University; Londrina/PR; $23^{\circ} 18^{\prime} \mathrm{S}, 51^{\circ} 09^{\prime} \mathrm{W}$ ) were studied from 1992 to 1997 . The wasp fauna was observed on four crops (from three plants; approximately 50 figs per crop) in Campinas and eight crops (from eight plants; approximately 40 figs per crop) in Londrina. Figs were sampled at the male phase and were placed individually in plastic flasks so all insects could emerge. Flasks were frozen and the total number of wasps by species was counted. The number of foundress pollinating wasps was evaluated on 64 crops sampled during the interfloral phase at Londrina and two others at Campinas. In addition, figs of the same two crops at Campinas were monitored weekly on the tree and dissected in the lab to analyse the development of the figs and associated organisms (e.g. fig wasps, fungus, nematodes and mites).

Voucher materials of plants are deposited in the UNICAMP (UEC) and UEL (FUEL) herbaria. Voucher insects, mites and nematodes are in possession of the senior author.

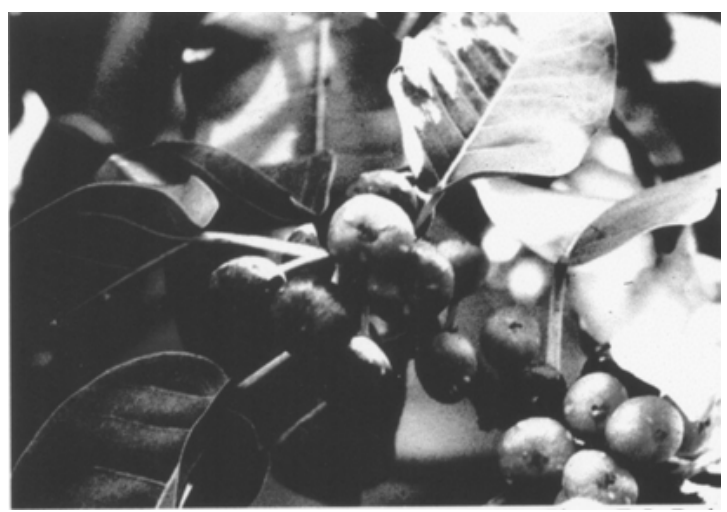

Figure 1. Branch of Ficus eximia with figs in the male phase (figs with $2-2.5 \mathrm{~cm}$ in diameter). Campinas/SP. Photo E.L. Borba.

\section{Results and Discussion}

Associated fig wasps - The pollinating species (Pegoscapus sp., possibly P. tonduzi (Grandi); W. Ramírez B., personal communication) and 14 nonpollinating species (table 1) were found in samples from Campinas and Londrina. Fig wasps associated with $F$. eximia belong to Agaonidae, Eurytomidae and Torymidae families (sensu Boucek 1988), and have different morphological, behavioural and biological adaptations to explore the figs (table 1). The wasp fauna associated to $F$. eximia may be considered intermediary in richness compared with those of African Ficus species, which range between 3 and 30 fig wasp species (Compton \& Hawkins 1992, Compton \& van-Noort 1992). However, the $F$. eximia fig wasp fauna was composed mainly of galler species (table 1), as found in fig wasp communities from the New and Old Worlds (Compton \& Hawkins 1992, West et al. 1996).

All females of pollinating and non-pollinating fig wasps of $F$. eximia are winged and fly in search of new figs to colonize, while males of the pollinating and some non-pollinating (Idarnes, carme and flavicollis groups; and Heterandrium) species are wingless (table 1), restricting their activities into the fig. Pollinator males are weak-pigmented, have small compound eyes and long telescopic gasters used for mating with females while they are still in their galls. Wingless non-pollinator males are also weak-pigmented and some possess well-developed mandibles and aggressive behaviour during the mating phase, as referred in literature (Hamilton 1979, Murray 1987).

Pollinating wasps and pollination - Ficus eximia pollinators are attracted to figs when female flowers are receptive (female phase). Studies have demonstrated that pollinator attraction is mediated through volatile chemicals released from figs in the receptive phase (van-Noort et al. 1989, Ware et al. 1993, Hossaert-McKey et al. 1994, Ware \& Compton 1994). The pollinator of $F$. eximia penetrates the ostiole crawling through the bracts, and its wings and parts of antennae usually break off during this process. On several occasions dead pollinators were observed among the ostiole bracts (figure 2) due probably to the closing bracts process (Janzen 1979a) or the re-emergence attempt from the fig 
Table 1. Upper categories, number of species by genus and characteristics of fig wasps associated with Ficus eximia. Resource utilization was based on field and experimental observations in Campinas/SP and Londrina/PR, as well as from data in the literature (West et al. 1996).

\begin{tabular}{|c|c|c|c|c|c|c|}
\hline Family & Subfamily & Genus & $\begin{array}{c}\mathrm{N} \underline{0} \text { of } \\
\text { species }\end{array}$ & $\begin{array}{c}\text { Morphology } \\
\text { of males }\end{array}$ & Pollination & $\begin{array}{c}\text { Resource } \\
\text { utilized }\end{array}$ \\
\hline Agaonidae & Agaoninae & Pegoscapus & 1 & Wingless & + & ovary tissue \\
\hline Agaonidae & Sycophaginae & Idarnes (carme group) & 3 & Wingless & - & ovary tissue \\
\hline Agaonidae & Sycophaginae & Idarnes (flavicollis group) & 1 & Wingless & - & ovary tissue \\
\hline Agaonidae & Sycophaginae & Idarnes (incerta group) & 1 & Wingless & - & ovary tissue \\
\hline Agaonidae & Otitesellinae & Aepocerus & 2 & Winged & - & ovary tissue \\
\hline Agaonidae & Otitesellinae & Heterandrium & 2 & $\begin{array}{l}\text { Winged and } \\
\text { wingless }\end{array}$ & - & ovary tissue \\
\hline Eurytomidae & - & Eurytoma & 2 & Winged & - & wasp larva (?) \\
\hline Torymidae & - & Physothorax & 2 & Winged & - & wasp larva \\
\hline Torymidae & - & Torymus & 1 & $\begin{array}{l}\text { Winged and } \\
\text { brachypterous }\end{array}$ & - & wasp larva \\
\hline
\end{tabular}

(Gibernau et al. 1996). The majority (35.8\%) of the figs were colonized by one foundress (figure 3 ), although supercolonization was common (20 foundress were found on one occasion).

Once inside the fig, the foundress wasp walks around on the platform composed by the stigmas of flowers (synstigma), pollinates female flowers removing pollen from its thoracic pollen pockets and corbiculae, and lays eggs in some of these flowers.

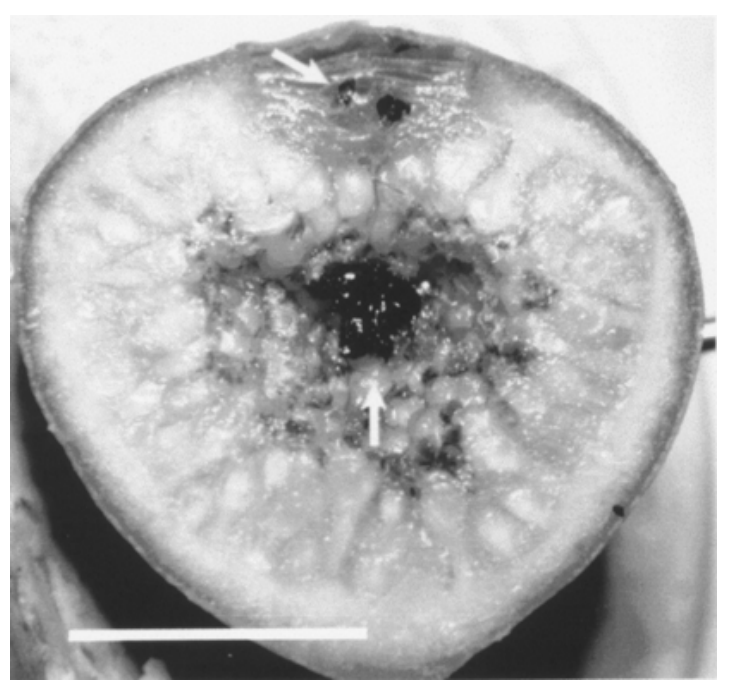

Figure 2. Fig of Ficus eximia in the interfloral phase. Dead foundresses in the ostiole and in the cavity of a fig (arrows). Scale $=5 \mathrm{~mm}$.
This process of active pollination, known as ethodynamic, occurs in pollinating species where specific pollen storing structure and behaviour patterns concerned with pollination are involved (Galil \& Meiri 1981, Joseph 1984). In F. eximia, like in other species (Galil \& Eisikowitch 1968, Janzen 1979b, Bronstein 1988a, Kathuria et al. 1995, Nefdt \& Compton 1996), pollinator eggs are preferentially laied in ovaries close to the fig lumen, while achenes develop on those near the fig wall. The pollinating species was the only one that oviposited on female flowers inside the cavity of the fig. Inner oviposition is also carried out by some non-pollinating fig wasps species from Old World Ficus groups (Galil \& Eisikowitch 1968, Compton 1993). After pollination and oviposition, the $F$. eximia foundress wasps do not leave the fig and die inside the syconium cavity (figure 2).

The development of fig wasp larvae and achenes takes place during some weeks (interfloral phase), and finishes when the anthers mature and the offspring of fig wasps emerge from their galls (male phase). A single adult wasp emerges from each galled ovary. Wingless males emerge first and use their long telescopic gasters to mate females when these are still in their galls. Then the mated female progeny emerge from their galls and actively collect pollen, storing it in their thoracic pollen pockets and 


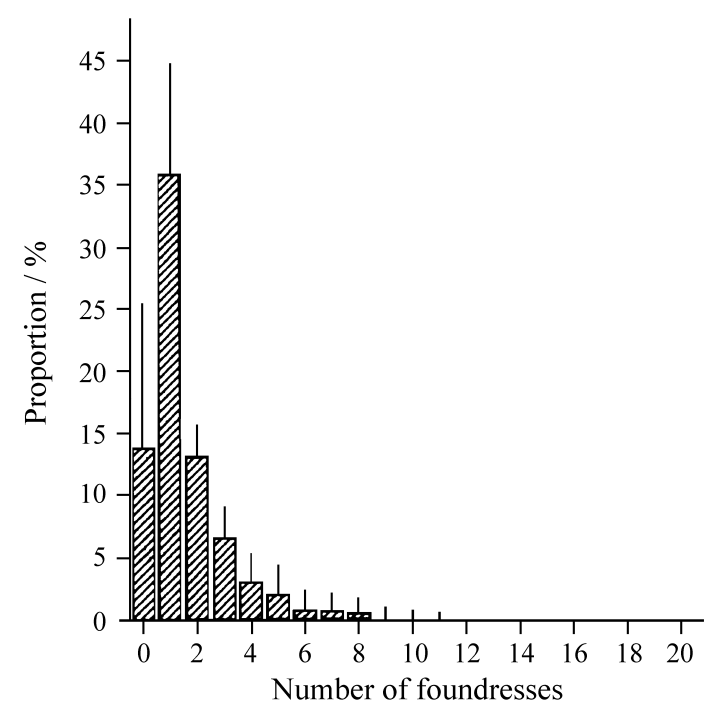

Figure 3. Distribution of number of foundresses in 66 Ficus eximia crops (two from Campinas/SP, n = 139 and 462 figs; and 64 from Londrina/PR, $\mathrm{n}=50$ figs each crop). The bars represent the standard deviation.

corbiculae. At the same time, the male progeny chew a communal exit hole, whereby female wasps leave the fig. The $F$. eximia pollinating offspring is highly female biased, a fact that has been interpreted as an adaptation to reduce the local mate competition in the fig "microhabitat" (Hamilton 1967, 1979, Frank 1985, Herre 1985, 1987, Ramírez 1987).

After dispersal of female fig wasps, $F$. eximia figs ripen and become attractive to frugivorous birds and bats (post-floral phase), as do other Ficus species (Janzen 1978, Coates-Estrada \& Estrada 1986, Lambert \& Marshall 1991, Figueiredo et al. 1995). Adult female pollinators survived 1.4 days on average ( $n=23$ wasps) under lab conditions, with maximum limit of two days. These wasps did not feed on diluted sugar solution, which could suggest that adult pollinators do not feed. These observations of short longevity and no feeding are in line with data on other Ficus pollinators species (Kjellberg et al. 1988, Compton 1993, Figueiredo \& Sazima 1997).

Non-pollinating wasps - Females of non-pollinating species arrive on F. eximia figs at the female phase, as do pollinators, or during the interfloral phase (data not shown). Although non-pollinators oviposite externally through the fig wall, they lay their eggs in ovaries close to the fig lumen (figure 4), which is possibly due to their long ovipositors. The preferential utilization of ovaries close to the fig lumen for both pollinators and non-pollinators has been interpreted as selection for oviposition site, which allows better larvae development. Galls developing near the lumen could be less space-stressed and/or a better access to females within these galls for mating, as suggested by Anstett et al. (1997). The use of the same pool of ovaries by pollinators and non-pollinators may be yet a reproductive strategy of the latter, since the fig tree could not develop a defence against a non-pollinating wasp without eliminating the pollinating larva (Bronstein 1991, West \& Herre 1994).

The oviposition of non-pollinating fig wasps on F. eximia prevented unpollinated figs from aborting (table 2), as observed in other studies (Galil \& Eisikowitch 1971, Bronstein 1991, Compton \& vanNoort 1992, Compton 1993, Cook \& Power 1996, West et al. 1996).

Brown spots were produced on the external surface of figs where non-pollinating fig wasps inserted their ovipositors. The number of spots was positively correlated with the quantity of non-polli-

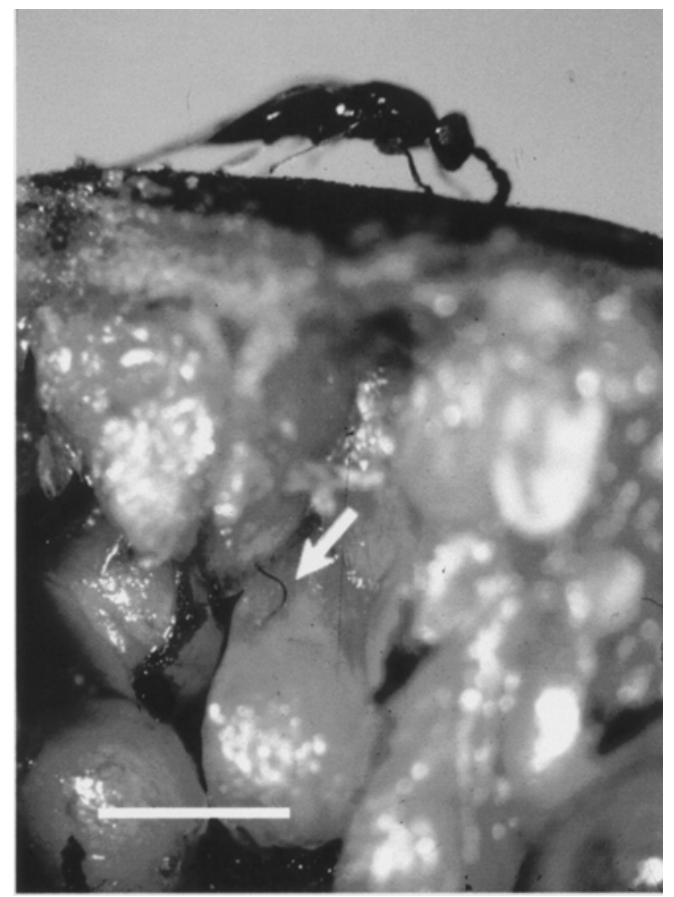

Figure 4. Longitudinal section shown an Idarnes, carme group, with the ovipositor inserted in an ovary near the lumen of the fig (arrow) of Ficus eximia. Scale $=1 \mathrm{~mm}$. Campinas/SP. 
Table 2. Number of unpollinated figs (without achenes and pollinator progeny) that reached full development and supported nonpollinator offspring, in crops of Ficus eximia sampled in Londrina/PR. N = number of figs sampled by crop.

\begin{tabular}{llc}
\hline Crop & N & Unpollinated figs \\
\hline 1 & 40 & 18 \\
2 & 38 & 27 \\
3 & 31 & 9 \\
4 & 38 & 7 \\
5 & 37 & 37 \\
\hline
\end{tabular}

nators reared in the figs $\left(r^{2}=0.531 ; p<0.001\right.$; $\mathrm{n}=214$ figs). Thus, the quantification of these spots may be used as an indirect measurement of the infestation level by non-pollinating fig wasps. On some occasions, remains of fig wasps ovipositors, probably predated during oviposition, were observed inserted in the figs (figure 5). Predation by ants is frequent when non-pollinating wasps fig arrive to oviposit (Bronstein 1988b, 1991, Compton \& Robertson 1988, 1991).

Each non-pollinating wasp of $F$. eximia develops into a galled ovary, as do pollinators. Non-pollinators emerge from their galls somewhat before or simultaneously to the progeny of pollinator, and leave the fig through the exit hole chewed by the pollinator males. Wingless males of Idarnes (carme

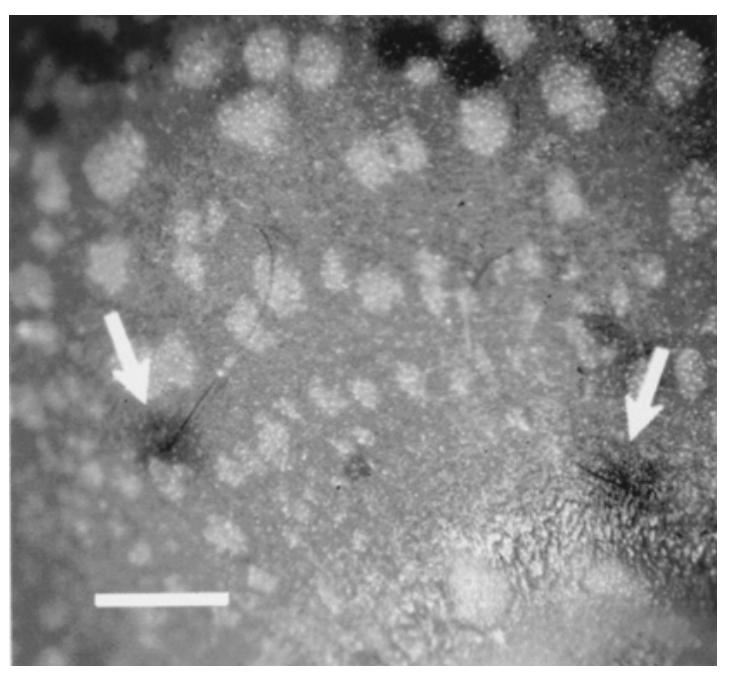

Figure 5. Remains of ovipositors (arrows) inserted in a Ficus eximia fig. Scale $=1 \mathrm{~mm}$. Campinas $/ \mathrm{SP}$. and flavicollis groups) emerged and were active for mating before emergence of pollinator males.

Females of non-pollinating fig wasp species of Aepocerus, Eurytoma, Heterandrium, Idarnes and Physothorax genus were kept alive for several days under lab conditions, and fed on diluted sugar solution. The use of sugar solution as nourishment increased experimentally the longevity of an Idarnes (carme group) species (data not shown). Some nonpollinating species naturally search for food sources when they are outside the figs (W. Ramírez B., personal communication). Thus, the capacity of feeding in nature could be a strategy of energy restoration that might increase the longevity of fig wasps and they ability to find figs in a suitable phase for colonization.

Other associated organisms - Organisms other than fig wasps were found associated with $F$. eximia figs. Curculionid (Coleoptera: Curculionidae) and a moth (Lepidoptera) were observed breeding in the figs in crops in Londrina. The larvae of these insects had consumed almost all contents of figs by the end of their cycles and negatively affected the development of fig wasps.

Nematodes, probably Parasitodiplagaster (Diplogasteridae), were found in association with pollinators and figs of $F$. eximia. Nematodes arrive within the female pollinators and reproduce in the fig lumen during the interfloral phase. A high number of nematode juveniles was observed at the beginning of the male phase. These juveniles infect the pollinator offspring as they emerge from their galls and are transported to other figs (Giblin-Davis et al. 1995). This interaction of nematodes with pollinating fig wasps and figs has been reported by many authors (Martin et al. 1973, Nadel et al. 1992, Vovlas et al. 1992, Herre 1993).

Mites (Tarsonemidae), foretic on female pollinators, were observed in crops in Campinas. Mites attach themselves to the lower part of the thorax of female pollinating wasps and as pollinators penetrate the fig, they drop off and reproduce among the bracts of the ostiole. Then at the end of the male phase, when female fig wasps are leaving the fig through the exit hole, mites attach themselves to pollinators and are taken to other figs. Twenty two percent of the figs $(n=120)$ in a crop sampled in Campinas had mites in the ostiole. This association 
has already been reported in Brazil (Hamilton 1979) as well as in other localities (Lindquist 1986, Ochoa et al. 1991, Nadel et al. 1992, Compton 1993, Ho 1994).

Fungus mycelia were present in the lumen of $12 \%$ of sampled figs $(n=244)$ in a crop in Campinas. W. Ramírez B. (personal communication) also observed fungi in figs of $F$. eximia in Costa Rica. These fungi do not apparently cause lesions in $F$. eximia figs, as do Fusarium moniliforme vectored on the body of pollinator of the edible fig, F. carica (Michailides \& Morgan 1994). However, more detailed studies will be necessary to evaluate whether the fungus observed in $F$. eximia has any effect on the fig - fig wasps interaction.

Ficus eximia shows a diversified assembly of interactions with several groups of organisms. High interaction diversity in syconia of Ficus appears to be more the rule than the exception in monoecious species, both in the Old and New World (Bronstein 1991, Nadel et al. 1992, Compton 1993). Thus, the present study is another indication of the large number of open lines of investigation concerning Ficus trees and their associates.

Interactions of Ficus and non-fig wasp organisms (e.g. fungi, mites and nematodes) certainly have important potential for (co)evolutionary approaches, as do comparative studies (Herre et al. 1996, Machado et al. 1996) of relationship of fig wasps and host species. Emphasis still needs to be placed on studies involving several interactions occurring together in a particular Ficus species, since this information is normally fragmentary in the literature. However, more detailed studies must be done to elucidate some points of biotic interactions and to consolidate patterns in F. eximia and other Ficus species.

\section{References}

ANSTETT, M.C., HOSSAERT-McKEY, M. \& KJELLBERG, F. 1997. Figs and fig pollinators: evolutionary conflits in a coevolved mutualism. Trends in Ecology and Evolution 12:94-99.

BOUCEK, Z. 1988. Australasian Chalcidoiea. CAB International, Wallingford.

BOUCEK, Z. 1993. The genera of chalcidoid wasps from Ficus fruit in the New World. Journal of Natural History 27:173217.
BRONSTEIN, J.L. 1988a. Mutualism, antagonism, and the figpollinator interaction. Ecology 69:1298-1302.

BRONSTEIN, J.L. 1988b. Predators of fig wasps. Biotropica 20:215-219.

BRONSTEIN, J.L. 1991. The nonpollinating wasp fauna of Ficus pertusa: Exploitation of a mutualism? Oikos 61:175-186.

BRONSTEIN, J.L. 1992. Seed predator as mutualists: Ecology and evolution of the fig pollinator interaction. In Insect-Plant Interaction. (E. Bernays, ed.). CRC Press, Boca Raton, p.1-43.

CARAUTA, J.P.P. 1989. Ficus (Moraceae) no Brasil: conservação e taxonomia. Albertoa 2:1-365.

COATES-ESTRADA, R. \& ESTRADA, A. 1986. Fruiting and frugivores at a strangler fig in the tropical rain forest of Los Tuxtlas, Mexico. Journal of Tropical Ecology 2:349-358.

COMPTON, S.G. 1993. One way to be a fig. African Entomology 1:151-158.

COMPTON, S.G. \& HAWKINS, B.A. 1992. Determinants of species richness in southern African fig wasp assemblages. Oecologia 91:68-74.

COMPTON, S.G. \& ROBERTSON, H.G. 1988. Complex interactions between mutualisms: ants tending homopterous protect fig seeds and pollinators. Ecology 69:1302-1305.

COMPTON, S.G. \& ROBERTSON, H.G. 1991. Effects of anthomopteran systems on fig-fig wasp interactions. In Antplant interactions. (C.R. Huxley \& D.F. Cutler, eds.). Oxford University Press, Oxford, p.120-130.

COMPTON, S.G. \& VAN-NOORT, S. 1992. Southern African fig wasps (Hymenoptera: Chalcidoidea): Resource utilization and host relationships. Proceedings of the Koninklijke Nederlandse Akademie van Wetenschappen, Series C, Biological and Medical Sciences 95:423-435.

COMPTON, S.G., WIEBES, J.T. \& BERG, C.C. 1996. The biology of fig trees and their associated animals. Journal of Biogeography 23:405-407.

COOK, J.M. \& POWER, S.A. 1996. Effects of within-tree flowering asynchrony on the dynamics of seed and wasp production in an Australian fig species. Journal of Biogeography 23:487-493.

CORNER, E.J.H. 1985. Ficus (Moraceae) and Hymenoptera (Chalcidoidea): Figs and their pollinators. Biological Journal of the Linnean Society 25:187-196.

CRANE, J.C. 1986. Fig. In Handbook of fruit set and development. (S.P. Monselise, ed.). CRC Press, Boca Raton, p.153165.

DEWOLF JR., G.P. 1960. Ficus (Tourn.) L. in Flora of Panama. (R.E. Woodson Jr. \& R.W. Schery, eds.). Annals of the Missouri Botanical Garden 47:146-165.

FIGUEIREDO, R.A. \& SAZIMA, M. 1997. Phenology and pollination ecology of three Brazilian fig species (Moraceae). Botanica Acta 110:73-78.

FIGUEIREDO, R.A., MOTTA JR., J.C. \& VASCONCELLOS, L.A.S. 1995. Pollination, seed dispersal, seed germination and establishment of seedlings of Ficus microcarpa, Moraceae, in southeastern Brazil. Revista Brasileira de Biologia 55:233-239. 
FRANK, S.A. 1985. Hierarchical selection theory and sex ratios. II. On applying the theory, and a test with fig wasps. Evolution 39:949-964.

GALIL, J. 1977. Fig biology. Endeavour 1:52-56.

GALIL, J. \& EISIKOWITCH, D. 1968. On the pollination ecology of Ficus sycomorus in east Africa. Ecology 49:259-269.

GALIL, J. \& EISIKOWITCH, D. 1971. Studies on mutualistic symbiosis between syconia and sycophilous wasps in monoecious figs. New Phytologist 70:773-787.

GALIL, J. \& MEIRI, L. 1981. Number and structure of anthers in fig syconia in relation to behavior of the pollen vectors. New Phytologist 88:83-88.

GIBERNAU, M., HOSSAERT-MCKEY, M., ANSTETT, M.C. \& KJELLBERG, F. 1996. Consequences of protecting flowers in a fig: A one-way trip for pollinators? Journal of Biogeography 23:425-432.

GIBLIN-DAVIS, R.M., CENTER, B.J., NADEL, H., FRANK, J.H. \& RAMÍREZ B., W. 1995. Nematodes associated with fig wasps, Pegoscapus spp. (Agaonidae), and syconida of native Floridian figs (Ficus spp.). Journal of Nematology 27:1-14.

GORDH, G. 1975. The compartive external morphology and systematics of the neotropical parasitic fig wasp genus Idarnes (Hymenoptera: Torymidae). University of Kansas Science Bulletin 50:389-455.

HAMILTON, W.D. 1967. Extraordinary sex ratios. Science 156:477-488.

HAMILTON, W.D. 1979. Wingless and fighting males in fig wasps and other insects. In Sexual selection and reproductive competition in insects. (M.S. Blum \& N.A. Blum, eds.). Academic Press, London, p.167-220.

HERRE, E.A. 1985. Sex ratio adjustment in fig wasps. Science 288:896-898.

HERRE, E.A. 1987. Optimality plasticity and selective regime in fig wasp sex ratios. Nature 329:627-629.

HERRE, E.A. 1993. Population structure and the evolution of virulence in nematode parasites of fig wasps. Science 259:1442-1445.

HERRE, E.A., MACHADO, C.A., BERMINGHAM, E., NASON, J.D., WINDSOR, D.M., MCCAFFERTY, S.S., VAN-HOUTEN, W. \& BACHMANN, K. 1996. Molecular phylogenies of figs and their pollinator wasps. Journal of Biogeography 23:521-530.

HO, C.C. 1994. A new genus and two new species of Tarsonemidae from Ficus spp. (Acari: Heterostigmae). International Journal of Acarology 20:189-197.

HOSSAERT-MCKEY, M., GIBERNAU, M. \& FREY, J.E. 1994. Chemosensory attraction of fig wasps to substances produced by receptive figs. Entomologia Experimentalis et Applicata 70:185-191.

JANZEN, D.H. 1978. A bat-generated fig seed shadow in rain forest. Biotropica 10:121

JANZEN, D.H. 1979a. How to be a fig. Annual Review of Ecology and Systematics 10:13-51.

JANZEN, D.H. 1979b. How many babies do figs pay for babies? Biotropica 11:48-50.
JOSEPH, K.J. 1984. The reproductive strategies in fig wasps (Chacidoidea: Hymenoptera) - a review. Proceedings of the Indian National Science Academy, Part B, Biological Sciences B50:449-460.

KATHURIA, P., GANESHAIAH, K.N., SHAANKER, R.U. \& VASUDEVA, R. 1995. Is there dimorphism for style lengths in monoecious figs? Current Science (Bangalore) 68:1047-1050.

KJELLBERG, F., DOUMESCHE, B. \& BRONSTEIN, J.L. 1988. Longevity of a fig wasp (Blastophaga psenes). Proceedings of the Koninklijke Nederlandse Akademie van Wetenschappen, Series C, Biological and Medical Sciences 91:117-122.

LAMBERT, F.R. \& MARSHALL, A.G. 1991. Keystone characteristics of bird-dispersed Ficus in a Malaysian lowland rain forest. Journal of Ecology 79:793-809.

LINDQUIST, E.E. 1986. The world genera of Tarsonemidae (Acari: Heterostigmata): a morphological, phylogenetic, and systematic revision, with a reclassification of familygroup taxa in the Heterostigmata. Memoirs of the Entomological Society of Canada 136:1-517.

MACHADO, C.A., HERRE, E.A., MCCAFFERTY, S. \& BERMINGHAM, E. 1996. Molecular phylogenies of fig pollinating and non-pollinating wasps and the implications for the origin and evolution of the fig-fig wasp mutualism. Journal of Biogeography 23:531-542.

MARTIN, G.C., OWEN, A.M. \& WAY, J.I. 1973. Nematodes, figs and wasps. Journal of Nematology 5:77-78.

MICHAILIDES, T.J. \& MORGAN, D.P. 1994. Dynamics of Blastophaga psenes populations, availability of caprifigs, and fig endosepsis caused by Fusarium moniliforme. Phytopathology 84:1254-1263.

MURRAY, M.G. 1985. Figs (Ficus spp.) and fig wasps (Chalcidoidea, Agaonidae): Hypotheses for an ancient symbiosis. Biological Journal of the Linnean Society 26:69-82.

MURRAY, M.G. 1987. The closed environment of the fig receptacle and its influence on male conflict in the Old World fig wasp, Philotrypesis pilosa. Animal Behaviour 35:488-506.

NADEL, H., FRANK, J.H. \& KNIGHT, R.J., JR. 1992. Escapes and accomplices: The naturalization of exotic Ficus and their associated faunas in Florida. Florida Entomologist 75:29-38.

NEFDT, R.J.C. \& COMPTON, S.G. 1996. Regulation of seed and pollinator production in the fig-fig wasp mutualism. Journal of Animal Ecology 65:170-182.

OCHOA, R., SMILEY, R.L. \& SAUNDERS, J.L. 1991. The family Tarsonemidae in Costa Rica (Acari: Heterostigmata). International Journal of Acarology 17:41-86.

PEREIRA, R.A.S., RODRIGUES, E. \& MENEZES JR., A.O. 1995. Fenologia de Ficus guaranitica Chodat \& Vischer. Semina 16:129-135.

RAMÍREZ B., W. 1987. The influence of the microenvironment - the interior of the syconium - in the coevolution between fig wasps (Agaonidae) and the fig (Ficus). In Insects-Plants. (V. Labeyrie, G. Fabres, \& D. Lachaise, eds.). W. Junk Publisher, Dordrecht, p.329-334. 
RAMÍREZ B., W. 1988. Parasitic relationships among chalcidoid fig-wasp and the syconia of Ficus (Hymenoptera: Chalcidoidea). in Advances in parasitic hymenoptera research (E. J. Brill, ed.). New York, p.345-350.

VAN-NOORT, S., WARE, A.B. \& COMPTON, S.G. 1989. Pollinator-specific volatile attractants released from the figs of Ficus burtt-davyi. South African Journal of Science 85:323-324.

VERKERKE, W. 1989. Structure and function of the fig. Experientia (Basel) 45:612-622.

VOVLAS, N., INSERRA, R.N. \& GRECO, N. 1992. Schistonchus caprifici parasitizing caprifig (Ficus carica sylvestris) florets and the relationship with its fig wasp (Blastophaga psenes) vector. Nematologica 38:215-226.

WARE, A.B. \& COMPTON, S.G. 1994. Responses of fig wasps to host plant volatile cues. Journal of Chemical Ecology 20:785-802
WARE, A.B., KAYE, P.T., COMPTON, S.G. \& VAN-NOORT, S. 1993. Fig volatiles: Their role in attracting pollinators and maintaining pollinator specificity. Plant Systematics and Evolution 186:147-156.

WEST, S.A. \& HERRE, E.A. 1994. The ecology of the New World fig-parasitizing wasps Idarnes and implications for the evolution of the fig-pollinator mutualism. Proceedings of the Royal Society of London, Series B, Biological Sciences 258:67-72.

WEST, S.A., HERRE, E.A., WINDSOR, D.M. \& GREEN, P.R.S. 1996. The ecology and evolution of the New World non-pollinating fig wasp communities. Journal of Biogeography 23:447-458.

WIEBES, J.T. 1979. Co-evolution of figs and their insect pollinators. Annual Review of Ecology and Systematics $10: 1-12$ 